\title{
Danske litteraturhistorikere om Bellman
}

af forfatteren Søren Sørensen

I så godt som enhver oversigt over Bellmanforskningen nævnes ét bestemt dansk værk. Det drejer sig om Torben Kroghs afhandling fra 1945 Bellman som musikalsk Digter 0 . Nu er det ganske vist ikke i egentligste forstand en litteraturhistorisk traktat, selv om den i sin tid blev udgivet af Det filologisk-historiske Samfund i rækken af Studier fra Sprog-og Oldtidsforskning, den hører med større ret hjemme i musikhistorien. - Udgivelsesåret skal man derimod lægge mærke til; det er 150-året for digterens dødelige bortgang.

Runde år ser ud til at have virket inspirerende på danske forskere - som også på danske digtere; dette seminar markerer 200-året med kun én dags forskydning; for 50 år siden tilegnede Fr. Lauterbach Svenska Gillet i København en studie, ikke mere end 10 sider, men dog 10 sider under overskriften Carl Michael Bellman og Danmark, og Torben Kroghs banebrydende undersøgelse kom som nævnt ved samme lejlighed, i 150-året. I tiden omkring 1895 og især efter 100-året kom der en sand vårflod af danske litteraturhistoriske behandlinger og med de store navne i spidsen - så vel som nogle mindre profeter; dog ikke Georg Brandes, han omtaler kun Bellman en passant i sin afhandling om Tegnér ${ }^{1}$.

I denne vårflod er det vigtigt at fremhæve tre behandlinger, nemlig 1) Valdemar Vedels analyse fra 1894 i værket Svensk Romantik, 2) Vilhelm Andersens ti år yngre i Bacchustoget i Norden og 3) O. Schonings Bellmans Digtning og dens Indflydelse $i$ Danmark som ligeledes udkom i 1904, men som egentlig er manuskriptet til en magisterforelæsning i 1899.

I Svensk romantik skildrer Vedel - tidstypisk - Bellmans poetiske univers som et centralt udtryk for svensk væsen og lynne, på den tid turde man endnu tale om 
"folkekarakterer"; i virkeligheden mente han bare de identitetsformende erfaringer, man havde gjort, og de påvirkninger, man i særlig grad havde tilegnet sig, således som i vore dage mentalitetshistorikere frit og frejdigt læser kilderne for at finde de fremherskende træk i en bestemt tidsalders tænkemåde.

For Valdemar Vedel var Bellman først og fremmest svensk. Han siger, at "Bellmansdigtningen har sine Rødder nede i de Lag af Svenskhed, hvortil Frihedstid og Franskhed ikke var nået ind"2. Det er Karl den XII's fyrighed, der behersker den med hvad Vedel kalder "Nordens Natur og Racens Hjerterødder"3. Dertil kommer nederst - som "Tilbageslag efter Oprømthedens og Enthusiasmens Højtryk, som selve Bunden i Racegemyttet - ligger det sørgmodige Tungsind" 4 . Og for det fjerde når Vedel så til det, der efter min læsning er det centrale i hans Bellmanforståelse, det, der efter min opfattelse er det mest interessante: han har øje for de religiøse dybder i drikkeviserne: "Man behøver kun at skrabe lidt paa det stockholmske og franske Lag, før man naaer ind til Pietisten i Bellman"5. - Det er også derfor jeg betegner Vedels bidrag som "en analyse"; hans gennemgang af den bellmanske produktion karakteriserer den ved fire væsentlige elementer, dvs. de bestanddele, der udgør digtningens egentlige væsen i ordets bogstaveligste betydning: a) det fandeni-voldske, som vi ser illustreret i den svenske historie, b) den nordiske naturfornemmelse, som så iøjnefaldende gennemlyser vore nationale sangskatte, c) det nordiske tungsind, der jo allerede gennemlyser både Edda og Kalevala, d) den inderlige og individuelle ansvarsfølelse over for Gud og verden som vi historisk og i Bellmans tilfælde må kalde pietismen, men som vi også kunne sætte andre etiketter på.

Vilhelm Andersens essayistiske behandling tager udgangspunkt i oldgræsk ånd, og det er på sin måde lige så rigtigt. "Vi ligner den Aand, vi begriber", skriver Vilhelm Andersen i sit forord 6 . For mig at se forholder det sig omvendt, at vi begriber den ånd vi ligner, men det er muligvis også det, Andersen i virkeligheden mener. Også Vilhelm Andersen har fat i, at Bellmans udgangspunkt er den lutherske mystik, men gør i modsætning til Vedel en efterfølger af Holberg og Brorson ud af ham, Holbergs efterfølger når det gælder indholdet, Brorsons efter formen.

Der er - med nogen ret - gjort grin med Vilhelm Andersen og Bacchustoget $i$ Norden i litteraturhistoriografien. Men der er også malm mellem mange slagger.

Harald Oscar Schoning - "der Dritte im Bunde" - har ikke på samme måde indskrevet sig i historien. Han endte som skolemand, og hans omdømme i den bran- 
che ved jeg ikke noget om. I modsætning til sine professorale kolleger er han den nøgterne forsker, der registrerer. Han er i og for sig også ude i et andet ærinde: Bellmans indflydelse i Danmark. Men han kommer naturligvis ikke uden om at karakterisere i hvert fald nogle af de egenskaber, der har givet Bellmans digtning indpas i Danmark. Som Vedel mener han at kunne sige noget om nabolandet: det mystisk-religiøse og det vegetative i menneskenaturen og støber følgende dogmatik: "Den svænske kultur staar i mange retninger oldkulturen nærmest og er dærfor lidt barbarisk endnu"7.

Størst betydning har Schonings afhandling, som jeg læser den, i dens systematiske analyse af de elementer i Bellmans digtning, som har øvet direkte indflydelse på dansk digtning - som sagt er det ikke så påfaldende, eftersom det har været det ærinde, han var ude i. Men i og med dette får han så også sagt noget væsentligt om Bellmans digtning. Han mener således, at den dramatiske livfuldhed i hele Henrik Hertz' digtning, både den del, der består af vers på bogsider og den, der udgøres af replikker på teaterscenen, står i dyb gæld til Fredmans Epistlar, den har, siger Schoning, "faaet ligefrem forbilledlig betydning for hans egen digteriske virksomhed"8. Desuden fremhæver han J.L. Heibergs egne udsagn om epistlernes grundlæggende indflydelse på udformningen af den heibergske vaudeville. Om Hostrup, der jo har gjort allerflittigst brug af de bellmanske melodier, siger han derimod, at den bellmanske digtning slet ikke har øvet nogen stilistisk indflydelse9, et udsagn, der måske nok kunne drøftes nærmere.

Tættest på det bellmanske forbillede kommer dog efter Schonings beskrivelse romantisten Carl Bagger i digtet "Promenaden om Natten" fra Smaadigte 1834 om to studenter, der skal lufte en regerlig brandert på Kongens Nytorv. - Man kunne også sige, at det er i det digt, forskellen mellem dansk viseepigoneri og svensk originalitet kommer tydeligst til udtryk ${ }^{10}$.

I kølvandet på 100-året så flere oversættelser dagens lys. Og Schoning nåede i 1904 at fremhæve hvorledes Edvard Søderberg i samlingen Gadens digte har den indtil da "sidste og sikkert mindst selvstændige efterligning af et bellmansk digt, fordi hele digtets tanke er lånt fra Bellmans berömte Ep. 2311. "Ack, du min moder" altså ..." Efter sigende har Søderberg aldeles afvist at kende noget til Epistel $23 ! 12$

Om Schonings afhandling må man retfærdigvis sige, at den i sit indhold virker velbekendt for den, der allerede måtte have læst den svenske litteraturforsker Karl 
Warburgs gennemgang af "Bellmansdikten i Danmark", der var trykt i Samlaren 1895 efter et foredrag i Vitterhetssamhället i Göteborg i februar samme år (NB: i 100-året!). På mange måder virker bogen om Bellmans Indflydelse i Danmark som en lærebog; man mærker pædagogen i form og udførelse.

\section{Bellman i læsebogen}

Imidlertid skrev Schoning intet om den indflydelse, Bellmans digtning har fået her til lands gennem pædagogikken - og allerede havde fået i 1899; dette emne hører til dem, Selskabet i fremtiden må tage sig for at gen-

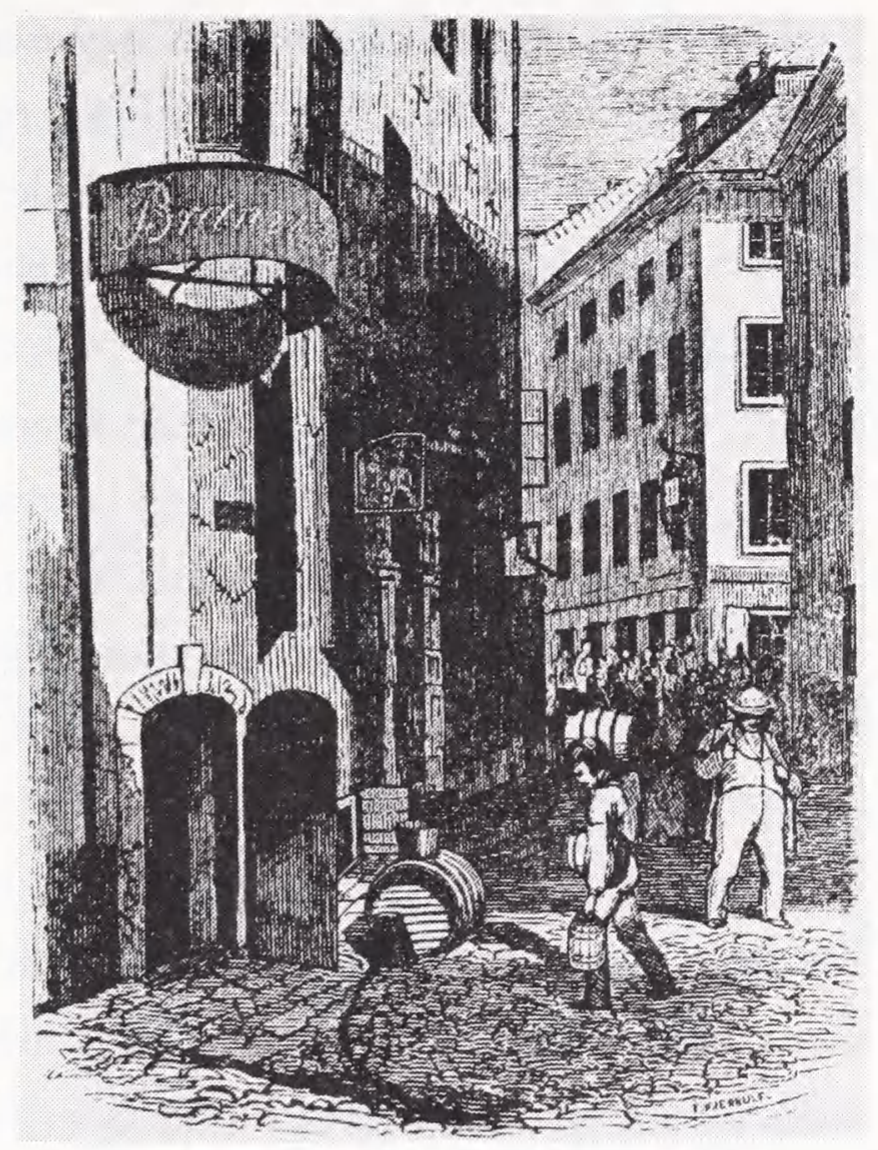

Österlånggatan med "Krypin" til venstre. Træsnittet stammer fra J.G. Carléns udgave af Bellmans Samlade Skrifter fra 1861. nemgå. Sagen er i hvert fald, at Bellman var en kendt skikkelse i danskundervisningen gennem allerede et halvt århundrede, da Schoning udsendte sin afhandling. Den egentlige introduktion til skolestuen indtraf i 1856, da forstanderen for Borgerdydskolen på Christianshavn, professor Martin Hammerich, udgav et indbydelsesskrift til afgangsprøven i form af et bind svenske vers af Bellman, Tegnér og Runeberg. Martin Hammerich (181181) har - nævnt i forbifarten - indskrevet sig i dansk lærdomshistorie som den første, der affattede en disputats på dansk, det skete i 1836. Han var i øvrigt en virksom oversætter (fra sanskrit) og egentlig foregangsmand for undervisningen i svensk og norsk i danske skoler.

Hans læsebøger var mønstergyldige, ikke mindst for de litteraturhistoriske oplysninger, han ledsagede sine tekstudvalg med. Det samme er gældende for forløberen til dem, Svenske Vers fra 1856. Vi mærker ved læsningen nok, at pædagogen skal føre sine disciple blidt og diskret ind i en verden, de strengt taget ikke burde stifte bekendtskab med. Han gør således meget ud af forholdet mellem virkelighed og digtning; nok er Fredman, Ulla Wiinblad, fader Berg et al. virkeligt eksisterende personer, men som de optræder i epistler og sange, er de digtninge. 
Det lykkes alligevel Hammerich at give en bedømmelse af den bellmanske digtning med ordene: "Disse Billeder af Livet, rige paa slaaende Træk og spillende i alle Stemningers Farver, fra de mørkeste til de lyseste, digtede i et Sprog af Ord og Rhythmer, som man ikke hos nogen Forfatter skal træffe paa eengang saa rigt og naturligt, gjorde dobbelt Virkning derved, at de ikke blot fremtraadte i Digt, men i Sang." 13 Det er her det hele: troskaben mod virkeligheden, rigdommen i billeder, omskifteligheden, det uovertræffelige i ordvalg og versekunst.

Man noterer sig også, at Hammerich fremhæver J.L. Heiberg som den store danske formidler af Bellman, hans discipel i digtning, hans advokat i æstetisk kritik.

\section{Skandinavismen og Bellman}

Med rette udpeger Borgerdydskolens rektor Hammerich også Heibergs foredrag "Bellman som comisk Dithyrambiker" som det centrale stykke litteraturhistorie i dansk Bellmanreception. Dette foredrag holdt Heiberg ved en fest i Skandinavisk Selskab december 1843, dvs. 14 måneder før 50 -året for digterens dødelige bortgang. Samme aften, umiddelbart før Heiberg gav sit foredrag, havde en anden fremtrædende Bellmanianer, digteren Carl Ploug, givet en biografisk skildring af Bellman.

Siden blev begge foredrag naturligvis trykt og slidt tynde af litteraturstuderende. Særligt Heibergs hævder sig, og det gør det ved to synsvinkler: 1) overvejelserne om det nære forhold mellem svensk og dansk i sproglig henseende, og 2) analysen af epistlerne.

Særligt vil jeg, hvad epistelanalysen angår, understrege det moment som Heiberg strejfer, men ikke begrunder nærmere, nemlig at Fredmans Epistlar er et epos, der må betragtes som "et sammenhængende Heelt, et Epos af den meest lyriske Characteer"14. I den moderne svenske forskning synes man at indse epistelsamlingens eposkarakter, således Hillbom i den videnskabelige udgave 1990. Selv lægger jeg megen vægt på det Heibergske helhedssyn, og finder det i øvrigt på det smukkeste bevist af den samlede indspilning, Bellmanssällskapet har udsendt på 6 cd'er ved årsskiftet 1994-95.

Men åstedet for de to foredrag - og den efterfølgende Bellmankoncert er interessant i mentalhistorisk sammenhæng: Skandinavisk Selskab. Det var nystiftet, da man fejrede Bellman, og kredsen af stiftere repræsenterer et vægtigt kapitel i dansk politisk historie: D.G. Monrad, J.F. Schouw, J.N. Madvig, H.N. Clausen; også Martin Hammerich var for øvrigt med $\mathrm{i}$ indbyderkredsen, sammen med Heiberg. 
Bellman læser ved lys.

Tegning af Johan Tobias Sergel.

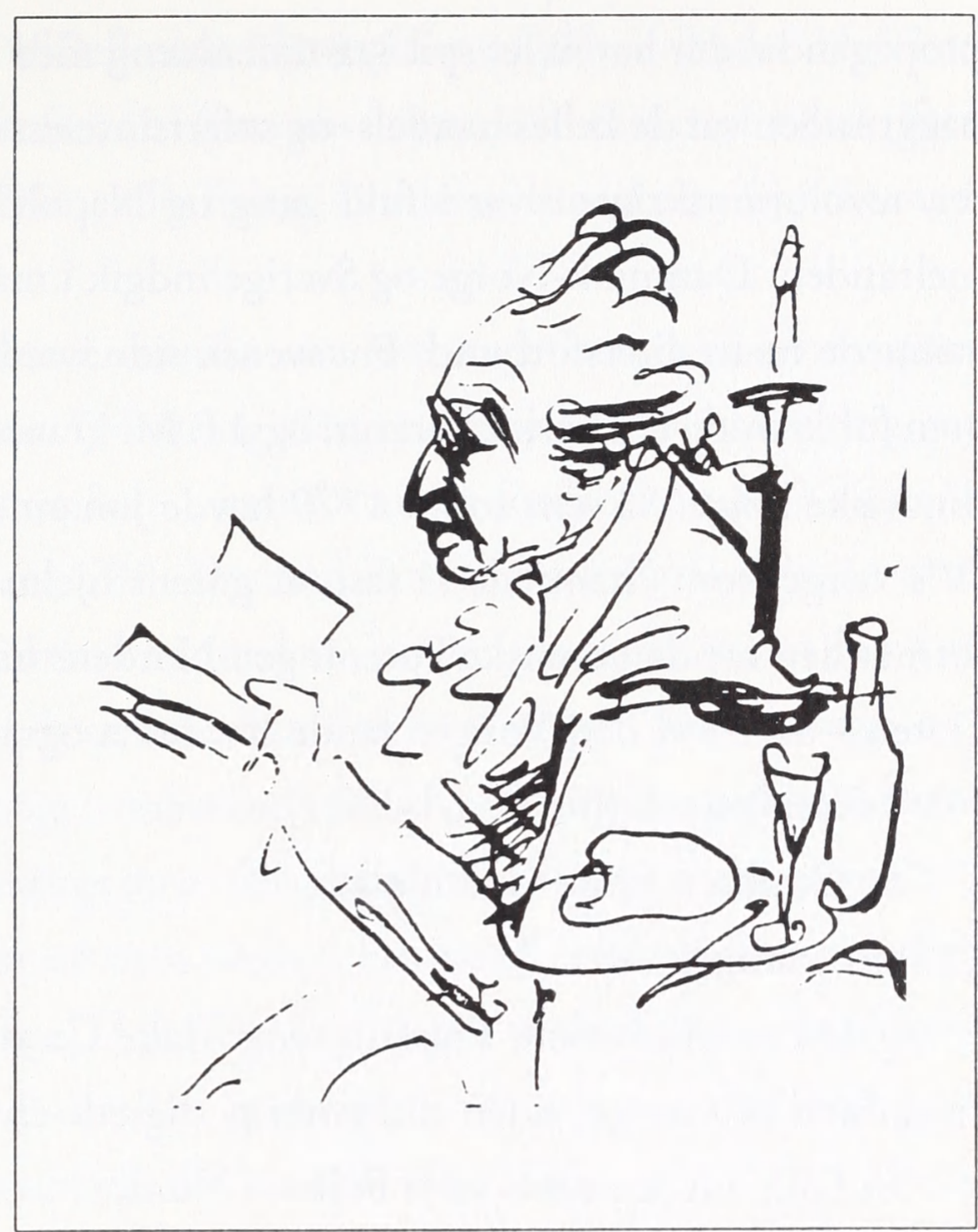

Listen over foredragsholdere er heller ikke uden interesse: N.F.S. Grundtvig, arkæologen J.J.A. Worsaae og kunsthistorikeren N.L. Høyen.

Der er nemlig et forhold, der synes at have haft afgørende betydning for Bellmanforståelsen her til lands; det er sammenhængen mellem en almen skandinavisk-nordisk orientering, en bred og almen optagethed af det nordiske på den ene side og interessen for Bellmans værk på den anden. Sammen med hver af de skandinavistiske, eller som vi siger i dag: nordistiske bølgetoppe, oplever vi tillige et bellmanistisk skumsprøjt. Det følger heraf, at interessen for Bellman i Danmark netop ikke er konstant gennem de forløbne 200 år.

En sådan bølgetop slog mod himlen $\mathrm{i}$ år for 200 år siden, året 1795 var et højdepunkt i den videnskabelige skandinavismes storhedsperiode. En vigtig del af baggrunden var, at en af de værste fjender i hele Danmarkshistorien var blevet fjernet i 1792; Gustav III var en ægte gottorper, en af de holstenske hertuger, der uophørligt pønsede på Danmarks fordærv, og den farligste, efter at Katarina den Store i 1762 havde fjernet Karl Peter Ulrich fra tsartronen i Rusland. Nå, alt det kan De læse om i min bog Dansk Alliancepolitik 1762-1972, det skal jeg ikke trætte med her, men det skulle blot nævnes som en modgift mod en alt for ivrig gustaviansk 
propaganda, der har så let spil i sammenhæng med Bellman ... Den vigtigste del af baggrunden var de fælles handels- og søfartsinteresser over for de krigsførende magter, revolutionskrigene var i fuld gang og Napoleonskrigene dæmrede ved himmelranden. Danmark-Norge og Sverige indgik i marts 1794 det første af en række væbnede neutralitetsforbund. Fra svensk side ivrede Bellmanudgiveren J.H. Kellgren for læsning af dansk litteratur, også F. M. Franzén levede ivrigt med i den skandinaviske bølge. Så sent som i 1779 havde Johannes Ewald skjaldet om Christian IV's værge, som "hamrede så fast, at gotens hjelm og hjerne brast". For at citere formanden for den svenske Foreningen Nordens historienævn, prof. Nils Andrén: Goten - det er vi det! Vore to lande havde da også været i krig i 1788. Men nu i 1795 skrev Jens Zetlitz (1761-1821) et svar:

"Se Cimbren favne Goten glad

som gammel Ven ..."

og den revolutionære Thisteddreng Malte Conrad Bruun, der snart skulle forvises, først til Sverige, siden til Frankrig, digtede en "Nordbosang":

"Et Folk, oh, kun eet, være Folket i Nord,

hvor er en Nation da på Jorden som vor?"

(Den, der heri hører et forvarsel om Wallins salme fra 1817 Vår konung och vårt fosterland, ser et bevis på, hvor almen tanken var på den tid).

\section{Jens Kragh Høst og andre}

I litteraturhistorien var det dog den unge jurist Jens Kragh Høst, der fik hentet Bellman ind i dansk dannelse. I 1794 udsendte han Forsog til en Udsigt over de skjonne Videnskabers Skjabne i Sverrig. For så vidt angår Bellman indeholdt netop dette værk en del realfejl, som han imidlertid loyalt gjorde opmærksom på i et tidsskrift, som har en særlig betydning i dansk Bellmanforskning, nemlig det nordiske kulturblad Nordia, som netop udkom i disse år og med Jens Kragh Høst som redaktør.

Fredmans Epistlarvar ilet i forvejen, hos Søren Gyldendal i Klareboderne var de at købe for fem rigsdaler. Høst nævner i tidsskriftet, at man allerede omkring 1780 kunne høre ... "ideligen", siger han, "Gubben Noach" og"Käraste bröder, systrar och vänner" og med en mentalhistorisk lækkerbidsken skriver han "selv i hæderlige og blandede Selskaber", dvs. selv blandt pæne mennesker og hvor der var damer til stede. Af oversættelser kendte han i 1795 kun lægen og visedigteren Rasmus Frankenaus "Se god Dag, min Vän, min Frände", "derimod er Ideen til Hr. Heibergs: Har 
jeg kun en lumpen Daler, laant af Bellmans När jag har en plåt at dricka"15. Vi er ikke meget klogere i dag, bortset fra, at Høst selv i samme nummer af tidsskriftet bringer oversættelsen af Ep. 35 "Kroen forfeile ei Brødrene kan/skønt sligt tør med Glassene hænde".

Om Bellmans poesi har redaktøren ganske vist ikke meget at sige på egne vegne; han kender naturligvis Fredmans Epistlar og Sånger, derimod har han aldrig set Bacchi Tempel 1783. Derfor citerer han - i en fortrinlig fordanskning - Kellgrens berømte forord til episteludgaven 1790. Dermed kan det naturligvis siges at være indlemmet i dansk litteraturhistorie, i og med at det skinner igennem, at Høst er enig med Kellgren. Efter god skik anfører han dog også et par tyske udsagn om Bellmans digtning, "men af et noget andet Indhold"16. Ifølge disse tyske kritikere synes Bellman "at holde selv smudsige og pöpelagtige Indfald for poetiske Licenzer"; en anden, som Høst antager for at være svensk, kritiserer Bellman for "alvorlige Tings Forvendelse til det Latterlige" 17 , hvilket naturligvis er aldeles korrekt. Alvorlige Tings Forvendelse til det Latterlige er en passende mærkat for Fredmandigtningen; man kunne sagtens opfatte det som en anbefaling.

Imidlertid vender Høst tilbage til Bellmankarakteristikken i værket Udsigt over den svenske Digtekunstes Skiabne 1804. Det sker på et tidspunkt, hvor Høst i øvrigt er engageret $\mathrm{i}$ at skrive lærebøger i svensk til brug for danske studerende. I denne bog er Høst fremdeles afhængig af Kellgren og fremdeles i opposition til de moralske tyskere, men nu har han også fået udviklet egne synspunkter; for at klargøre, hvad det er epistlerne giver, jævnfører han med billedkunsten, den store barokke samtidsskildring, hos malere som italieneren Caravaggio (1573-1610) og hollænderen Adriaen van Ostade (1610-84); det er selvsagt Ostades værtshusscener, der giver associationerne. Begge malede dramatisk og med stærke kontraster, hvilket berettiger til sammenligningen.

Høst fremhæver ligeledes med stor styrke Bellmans samtidige beherskelse af poesi og musik. Mere end én god side ofrer han ham alligevel ikke.

Trumfen i dansk litteraturhistorie, når det gælder Bellman, falder imidlertid uden for de runde års markeringer. Den stammer fra 1817, og dette årstal kan ikke komme på plads; skal man opføre sig som stedmoderen i Askepot, kunne man sige, at det dog nærmer sig 25-året. Hånden, der sidder inde med vor litteraturhistories bedste trumf, tilhører til gengæld en af dansk litteraturhistories største gnavpotter. Hans vrantne og irritable væsen var en fabel for samtiden, bl.a. når den gik ud over 
Ingemanns og Hauchs romaner; hvis jeg husker ret, var han også ganske hård ved H.C. Andersen. Hans brevveksling med svenske venner er publiceret, og her giver han minsandten gerne råt for usødet. Til gengæld må han mindes i dette hus som en af the founding fathers, i dansk bibliotekshistorie står der i det hele taget glans om hans navn. Og hvad er så hans navn? Jo: Christian Molbech (1783-1857).

I trebindsværket Breve fra Sverrig i Aaret 1812, som udkom i København 181417 , kombinerede han rejsebeskrivelse med historie, kulturoplysning, foregreb på sin måde både H.C.Andersens rejsebog og Selma Lagerlöfs læsebog for folkeskolen - muligvis bedre kendt som Nils Holgerssons underbara resa genom Sverige.

Molbech har om nogen blik for Bellmans originalitet. Hans dom over Bellmans digtning, fremsat blot en snes år efter digterens dødelige bortgang, er den, der 200 år senere er den almene overalt i Europa, at der er tale om "de fortrinligste og mest originale bacchiske Dithyramber, som vel i noget nyere Sprog ere frembragte" 18 . "... ikke blot det første af alle svenske Digtere (...); men ogsaa den eneste fuldkommen originale og nationale; maaskee ogsaa den, som hidtil med den høieste Genialitet har brudt Poesien en egen Bane i det svenske Tunge-maal ..."

Molbech vil dog ikke indlade sig på en æstetisk kritik, for det har tyskeren E. M. Arndt allerede gjort træfsikkert. I stedet tegner Molbech så hans levned, siger han. Og giver en af de mest præcise gennemgange af Bellmans digtning, jeg har mødt. Molbechs overlegenhed som polemiker fornægter sig ikke i denne tekst. Dumme kritikere har forset sig på det umoralske og lave; godt, siger Molbech, men tag og læs, hvad det er Bellman faktisk har skrevet: "Uanstændig og usømmelig er han kun for dem, der af Mangel på komisk Sands eller af utidig Peenhed misforstaae ham." 19 Det lave? Men det idealiseres jo ikke, det skildres jo, og så går han i Høsts fodspor og spørger, om Rembrandts og Ostades værker have noget Konstværd? Bellmans kunst er større, ifølge gnavpotten Molbech. "Lyset i de komisk-humoristiske Scener mangler ikke altid den tragiske Skygge", fremhæver han, de pragtfulde naturskildringer behandles for sig, sammenhængen med musikken betoner han, og i vor bedømmelse og berømmelse af Heibergs 1843 -foredrag er det godt at huske, at det her afsløres, i hvilket omfang Heiberg har skrevet af efter Molbech.

Molbech er også den første, der fortæller, at han har hørt Bellmans sange sunget, "og jeg regner det til de fortrinligste og mest eiendommelige Nydelser, som min Reise i dette Land har skienket mig." Dette land er altså Sverige.

Det meste af det, eftertidens danske litterater har været optaget af og søgt at 
udbygge, fandtes med andre ord så at sige fra begyndelsen af. Molbechs otte sider er grundteksten i dansk Bellmanforskning.

\section{Litteraturliste}

Vilhelm Andersen: Bacchustoget i Norden. Kbh. 1904.

Georg Brandes: Samlede Skrifter III. Kjbh. 1900. Julius Clausen: Skandinavismen historisk fremstillet. Kbh. 1900.

Martin Hammerich:Svenske vers af Bellman, Tegnér og Runeberg. i: Indbydelsesskrift til Afgangsprøven og Aarsprøven i Borgerdydskolen paa Christianshavn. Kjbh. 1856.

J.L. Heiberg: Bellman som comisk Dithyrambiker. i: Tvende Foredrag holdte den 20 de December 1843 i det skandinaviske Selskab Kjbh. 1844.

Jens Kragh Høst: Forsøg til en Udsigt over de skjønne Videnskabers Skjabne i Sverrig. Kjbh. 1794.

Jens Kragh Høst: Nekrologi i Nordia. April 1795 Kbh. 1795.

Jens Kragh Høst: Udsigt over den svenske Digtekunstes Skiabne i nyeste Tid. Kjbh. 1804.

F.J. Billeskov Jansen: Den danske Lyrik 18001870. Andet halvbind. Kbh. 1967.

Torben Krogh: Bellman som musikalsk Digter. Kbh 1945. Studier fra Sprog- og Oldtidsforskning udgivne af Det filologisk-historiske Samfund nr. 196.

Fr. Lauterbach: Carl Michael Bellman og Danmark. Tilegnet svenska gillet i København. Kbh. 1945.

Chr. Molbech: Breve fra Sverrige i Aaret 1812. Kjbh 1817

Chr. Molbech: Christian Molbechs brevveksling med svenske forfattere og videnskabsmand. Ved Morten Borup. Gleerup. Kbh. 1956.

Carl Ploug: Carl Michael Bellmans Liv i : Tvende Foredrag holdte den 20de December 1843 i det skandinaviske Selskab. Kjbh. 1844.

O. Schoning: Bellmans Digtning og dens Indflydelse i Danmark. Studier fra Sprog-og Oldtidsforskning udgivne af Det philologiskhistoriske Samfund Nr. 63. Kbh. 1904.

Edvard Søderberg: Gadens Digte. (Opr. udg. i Kbh. 1900.)

Søren Sørensen: Dansk Alliancepolitik 1762-1972. Lyngby. 1989.
Valdemar Vedel: Svensk Romantik. Kbh. 1894.

Karl Warburg: Bellmansdikten i Danmark. Föredrag i Göteborgs Kongl. Vet. o. Vitterhetssamhälle (vid Februarisammanträdet 1895). 1895 .

\section{Noter}

0 Således af bl.a. Gunnar Hillbom i Epistlarnas värld. Sth. 1994 p. 59.

1 Fra 1878 (Samlede Skrifter 3. bd. Kbh. 1900 p. 480$)$.

2 Op.cit. p. 25

3 Ibidem.

4 Ibidem.

5 Op.cit. p.28.

6 Op.cit. p.5.

7 Op.cit. p.4.

8 Op.cit. p.41.

9 Op.cit. p. 54.

10 Hvilket kunne kræve en nærmere udredning, der imidlertid må vente til anden lejlighed. Gunstige læser kan selv slå efter hos Bagger og gøre sig sine tanker.

11 Op.cit. p. $56 f$.

12 Jeg finder heller ikke Schonings argumentation ganske overbevisende i forhold til Søderbergs digt; dels er der en mulig fælles afhængighed af temaet i Jobs bog, dels er der lignende omstændigheder i den sociale baggrund for Fredmans epistel og Søderbergs københavnske slummiljø. En afgørende forskel er Søderbergs sociale karakteristik af de forbandede forældre, Fredmans ophav skildres som pæne mennesker der går til brudeskammel, indretter sig med møbler osv.

13 Op.cit. p.23f.

14 I Prosaiske Skrifter III p. 50.

15 Op.cit. p. 96.

16 Op.cit. p.95.

17 Op.cit. p.96.

18 Op.cit. p. 282.

19 Op.cit. p.284. 